\title{
Green Economic Development Policy in Vietnam in the Context of Global Climate Change
}

\author{
Tran Thi Huong \\ Academy of Journalism and Communication, Hanoi, Vietnam
}

\begin{abstract}
While sustainable development targets as established in the millennium development goals have not yet been achieved, the "brown economy" model has been destroying the environment and degrading natural resources. Developed countries are transitioning from industrial economy to post-industrial economy and gradually to knowledge-based economy. The global economic models are shifting from "brown economy" to "green economy". Today, more than ever, greening of development is defined as the approach to achieve sustainable development in the context of climate change. Being a developing country, Vietnam has been severely affected by the increasing impacts of climate change. The National Strategy for Green Growth and the National Strategy for Climate Change with vision towards 2045 which was passed and implemented has proven the determination of Vietnam to achieve sustainable development in the context of climate change by developing a green economy.
\end{abstract}

Keywords: green economy, development of green economy in Vietnam, global climate change

\section{Global Climate Change and the Need for Green Economic Development in Vietnam}

Climate change is a globally concerned issue, especially when the climate change speed is exceeding the forecast and when human activity is an increasing cause of climate change. Climate change has been directly affecting the socio-economic development of individual countries and the global environment.

According to the United Nations Framework Convention (1992), climate change means a change of climate which is attributed directly or indirectly by human activity that alters the composition of the global atmosphere, as well as natural climate fluctuations observed over comparable time periods. The average global temperature increase and the rise in sea levels are usually considered the two main signs of climate change.

Climate change is due to two groups of causes: The first is natural causes (due to the movements of tectonic plates forming continents and oceans leading to changes in regional and global climate patterns; minor changes in the earth orbit; and volcanic events); the second is man-made causes (due to the increase in human activities that produce greenhouse gas or the overexploitation of bodies that absorb or store greenhouse gas such as ecosystems, forests, etc.). According to the World Meteorological Organization, the atmospheric greenhouse gas concentrations in 2015 had exceeded 400/106 volume, meanwhile, while the safety limit of this indicator is only 350/106 volume. The surface temperature of the earth is increasing rapidly; from 1951 to 2012 , it increased by about 0.72 degrees Celsius. This is reflected in the decrease in the number of cold days per year and the marked increase in the number of hot days and heat waves per year. The average global sea level rose by $1.7 \mathrm{~mm}$ per year from 1900 to 1992 and $3.2 \mathrm{~mm}$ per year from 1993 to 2010. Meanwhile, regarding rainfall,

Tran Thi Huong, Ph.D. in Political Science, lecturer, Academy of Journalism and Communication, Hanoi, Vietnam. 
there were more regions with increased precipitation than regions with decreased precipitation. People over the world is showing more concerns regarding the increasing frequency of strong storms, especially super-storms with unprecedented wind speed.

In recent years, many serious natural disasters such as severe storms, intense heat, floods, droughts, and extreme weather have caused much loss in terms of human lives and properties. Vietnam is considered as one of the countries most severely affected by climate change, with its Mekong Delta being one of the world's top-three deltas that are most vulnerable to sea level rise. According to the 2016 climate change scenario for Vietnam, compared to the baseline period (1986-2005), the temperature of areas in the country has risen. It is also forecasted that rainfall will continue to increase in all parts of the country. According to the average scenario, at the beginning of the century, the average precipitation per year is expected to increase by $5 \%-10 \%$ in most parts of the country; during the middle of the century, it is expected to increase by $5 \%-15 \%$ and even over $20 \%$ for Red River Delta, North Central, and Mid-Central coastal provinces. According to the high scenario, the average precipitation per year is expected to increase similarly to the average scenario. It is notable that at the end of the century, the highest rate of increase can reach over $20 \%$ in the North and Mid-Central regions, as well as in parts of the South and Central Highlands.

In addition to that, the average sea level rise in Vietnam is likely to be higher than the global average. It is predicted that if the sea level rises by 1 meter and no solutions are found, about $16.8 \%$ of the Red River Delta area, $1.5 \%$ of the Central coastal provinces area (from Thanh Hoa to Binh Thuan), 17.8\% of the Ho Chi Minh City area, and $38.9 \%$ of the Mekong Delta area will be in submergence risk (Tran, 2016).

The serious impacts of climate change on Vietnam have been and are going to be impeding the implementation of the Millennium Development Goals and the sustainable development of the country. This demands new development management tools and changes in the current development paradigm to address the issues of sustainable development. The economic model of transition that has been agreed upon by many countries in the world, including Vietnam, is green economy. The current challenges in protecting the environment and combating climate change in Vietnam will be addressed by green economic development policies.

\section{Green Economy and the Challenges Proposed to Vietnam During the Development of a Green Economy}

\section{The Concept of Green Economy}

The phrase "green economy" was officially used at the United Nations Conference on Sustainable Development (June 2012) in Rio de Janeiro, Brazil (Rio+20) by the international community. Prior to the conference, the adjective "green" had been commonly utilized, mainly to describe a number of activities which were oriented towards sustainable development; for example, green consumption, green lifestyle, green products, etc. In such context, "green" was mostly interpreted as "environmentally friendly".

Various definitions of green economy have been presented; among which the one proposed by the United Nations Environment Program (UNEP, 2011) in the book of Towards a Green Economy-Pathways to Sustainable Development and Poverty Eradication (Vietnamese official name: Huớng tới nền kinh tế xanh-Lộ trình cho phát triển bền vũng và xoá đói giảm nghèo) has been most frequently quoted by scholars in Vietnam. According to UNEP: 
A green economy is one that raises people's living standard and improves social equality, at the same time drastically reducing environmental risks and ecological deficit. In short, green economy has a low emission rate, utilizes resources efficiently and orients towards social equality. (Vietnam Association for Conservation of Nature and Environment, 2018, p. 32)

Up to this point, concepts and awareness about green economy have not yet been clear since different understandings and interpretations are still being used. Western countries refer to it as green economic model; developing countries are striving towards green development strategy (China has proceeded to change the approach to economic development with the main focus on green development and building an ecological civilization; Thailand addresses this issue as "sufficiency economic model").

Regardless of the approach, all of the concepts view green economy as having three pillars: economic development (economic growth, jobs, etc.), environmental sustainability (reduction of carbon energy and the deterioration of natural resources, etc.), and social consolidation (ensuring the goal of poverty reduction, assuring the quality to opportunities created by the green economy, and generating healthy living environment).

Hence, it could be understood that green economy has a strong bond with sustainable development, in which, the official definition of green economy came to existence later, with regard to climate change. Green economy does not only include economic goals but also more importantly its notion to extend to social and ecological goals. Green economy, by nature, is also sustainable development; to be more specific, it is a method of sustainable development in the context of climate change, emphasizing many aspects of environmental resources. In a green economy, environmental resources are considered a decisive factor in the growth of the economy, the improvement of the value chain and the assurance of stability as well as long-term prosperity. Environmental resources sustainability and the response to climate change are the main focus of green economy. Though the definition of "green economy" cannot replace that of "sustainable development", it is gradually being recognized as an appropriate model for the foundation of sustainable development. In other words, a green economy is the economic strategy which can be applied to obtain the goals of sustainable development.

\section{The Significance of a Green Economy}

In the context of the digital era and global climate change, green economy plays a significant role regarding:

Firstly, a green economy contributes to the reduction of climate change. According to policy-makers, if $1.25 \%$ of global GDP invested to increase energy efficiency in all sectors and develop renewable energy including second-generation biofuel, there would already be a decrease in energy consumption rate up to $36 \%$ in 2030, and the annual $\mathrm{CO}_{2}$ emission would fall from 30.6 billion tons in 2010 to 20 billion tons in 2050. In addition, because of green agriculture, greenhouse gas can be decreased to $450 \mathrm{ppm}$ in 2050 . This number is deemed suitable and sufficient to curb global warming at the limit of 2 degrees Celsius (Nguyen, 2016).

Secondly, green economy helps conserve and enrich natural resources. According to the United Nations Educational, Scientific and Cultural Organization (UNESCO) (2011), green investments in forestry and agriculture will help reverse the current trend of forestry land deterioration and will regenerate approximately 4.5 billion ha of this important resource in the next 40 years. Investment in green agriculture will improve productivity, which means an increase in quantity of food production and a reduction in the amount of land used for agriculture as well as husbandry by $6 \%$ and enhance the quality of agriculture land by $25 \%$ in 2050 . Moreover, investing in increasing water supply sources, promoting the accessibility, and improving the management will 
increase the global water supply by $10 \%$, both in the short term and long term. Additionally, the underground water and surface water resources will be preserved (Nguyen, 2016).

Thirdly, a green economy contributes to alleviating famine, reducing poverty, guaranteeing social equality, and generating jobs. Striving towards a green economy is deemed as one of the approaches to alleviation of famine, reduction of poverty, and overall improvement of living standards. According to a green economy investment plan, $2 \%$ of global GDP will be distributed to "green" the energy, transportation, construction, waste management, agriculture, fisheries, water management, and forestry sectors. Green economy will provide the world with the energy that can support 1.4 billion people who are in shortage of electricity as well as more than 700 million others who cannot access the modern energy services (Nguyen, 2016). The technology of renewable energy, for instance, solar energy, wind energy and supporting policies promise to significantly contribute to the improvement of welfare and health of a low-income group, especially for people who currently do not have access to energy.

The United Nations Conference on Sustainable Development, Rio+20, in 2012 had issued an important document named "The future we want" and decided to spend 323 billion dollars on the initiative of Ban Ki-moon, the Secretary-General of the UN, called "Sustainable energy for all" with the purpose of guaranteeing that more than 1.3 billion people in under-developed country will be able to access to clean and sufficient energy in 2030 .

It is indisputable that sowing the seed of green economy to procure green growth will be the strategy of sustainable development in the future and the inevitable trend of the majority of countries in the world.

On the other hand, the reality in several countries also has shown that the promotion of green growth or the transition to a green economy will create great opportunities for a country to obtain a sustainable development at an unprecedented rate. To developing countries in particular, green growth will create the boost for an economic leap.

\section{Challenges to Vietnam During the Development of a Green Economy}

The reality of developing the country in these years has shown that the environmental issues have been creating a pressure on the long-term sustainable development of Vietnam. Economic growth in recent years has been at a considerable cost in terms of the environment. The rapid deterioration of natural resources is a major concern. Pollution from industrial and urban domestic sewage has been creating a severe impact on people's health, especially on children living in areas around Hanoi and Ho Chi Minh City. In a near future, Vietnam is one of the nations most affected by climate change, in which the population and livelihood of the Mekong Delta will suffer the highest risks. Those risks even rise due to the increasing energy consumption rate and the dependence on coal energy. In recent years, the greenhouse gas emission of Vietnam has a high ranking in the world ${ }^{1}$.

Currently, Vietnam is confronting four major challenges regarding climate change, namely: (1) the depletion of natural resources; (2) the downfall of environmental quality; (3) the risks of climate change; and (4) the increasing energy consumption rate.

Vietnam relies on natural resources more than other nations in the region. Almost half of the labor force has to live off agriculture or land in various ways. Land erosion has increased the frequency and severity of flood for agricultural land and people living downstream.

\footnotetext{
${ }^{1}$ See: http://dangcongsan.vn/kinh-te-va-hoi-nhap/phat-trien-kinh-te-xanh-trong-boi-canh-hoi-nhap-va-phat-trien-ben-vung-47486 6.html.
} 
In Vietnam, the quality of land, water, and air has drastically been worsened. The quality of air has also decreased due to the consumption of fossil fuel in electricity generation, industrial activities, and transportation. The low quality of air is the main cause of the high rate of respiratory diseases in under-five-year-old children. Due to this issue, there are approximately 4,000 cases of early deaths related to coal energy. In urban areas, pollution caused by domestic and industrial wastewater has contaminated water sources, negatively affecting the economy. Though no comprehensive review has been submitted, the impact on human's health is extremely severe.

Consequences caused by the unsustainable consumption of resources and the depletion of the environment have been further exacerbated by the reality of climate change. Vietnam is one of the countries most affected by climate change due to the geography, the high density of population in low delta region as well as an economy that highly depends on sectors vulnerable to climate change.

In Vietnam, the energy consumption increases faster than any other nations in the region, especially the consumption of electricity. The intensity of energy consumption in Vietnam is among the highest in the world. One of the reasons which lead to such situation is the inefficient energy consumption.

In the context of rapid changes all around the world and facing these challenges, Vietnam, as well as other countries, in order to not be left behind, is striving to catch up with the world, with the era, and especially with the worldwide trend of green development.

\section{Green Economic Development Policy in Association With Sustainable Development, Mitigation, and Adaptation to Climate Change in Vietnam}

The policy of sustainable development and green growth has been paid attention over many years by the Party and the Government.

The 12th National Congress (January 2016) reaffirmed the policy of "fast and sustainable development" and green economy development. The document of the 12th National Congress emphasizes ensuring rapid and sustainable development on the basis of macroeconomic stability and continuously improving productivity, quality, efficiency, and competitiveness; balancing between extensive and intensive development, while focusing on intensive development; promoting knowledge economy and green economy; economy development going hand-in-hand with cultural and social development, environmental protection and active response to climate change; ensuring national defense and security to maintain peace and stability (The Communist Party of Vietnam, 2016, p. 270).

In 2004, the Prime Minister issued Decision No. 153/2004/QD-TTg dated 17th August 2004 on Strategic Orientation for Sustainable Development in Vietnam (Vietnam Agenda 21). This is a strategic framework that includes major orientations as the legal basis for ministries, sectors, localities, organizations, and individuals to follow and show Vietnam's commitment to the international community. Strategic orientation for sustainable development in Vietnam indicates that sustainable development is an urgent need and an indispensable trend in the process of development. Therefore, it has been approved by countries around the globe as the agenda for each period of development. Many countries have been developing and implementing Agenda 21 on Sustainable Development.

Strategic Orientation for Sustainable Development in Vietnam advocates the challenges that Vietnam is facing, setting out guidelines, policies, legal instruments, and priority fields for action to be taken in order to secure sustainable development in the 21 st century. In terms of economy, it states that the prior actions are 
implementing "clean industrialization", building "green industry", namely ${ }^{2}$ :

(1) Adopting a more environment-friendly model of production, technology, a model of consumption based on the limited use of non-renewable resources, minimal disposal of waste that is harmful and difficult to decompose, and the balance between the lifestyle of individual, society, and nature.

(2) Maintaining rapid and stable economic growth by constantly improving the efficiency, scientific and technological advance, minimizing the use of natural resources, and protecting the environment.

(3) Developing agriculture and rural areas sustainably. While producing more and more commodities required by the market, it is important to ensure food safety, preservation and development of natural resources such as land, water, air, forests, and biodiversity.

(4) Building regions and local communities to thrive sustainably.

(5) Implementing clean industrialization, which requires planning the industrial development with the structure of industries, technologies, and equipment built on principles of environment friendliness from the start; actively preventing and treating industrial pollution, building a green industry.

(6) Implementing the strategy of clean industrialization, which means planning the industrial development with the structure of industries, technologies and equipment following principles of environment friendliness from the beginning; actively preventing and treating industrial pollution, building a green industry. Moreover, environmental standards should be included in the list of the most essential criteria for selecting industries that encourage investment, production technology and products, planning industrial parks and export processing zones, and constructing plans for prevention, treatment and control of pollution.

On April 12, 2012, the Prime Minister issued Decision No. 432/QD-TTg approving Vietnam Sustainable Development Strategy for 2011-2020, stating:

Sustainable development is a requirement throughout the development process of the country. Economic development needs to be combined closely, reasonably and harmoniously with social development, protection of natural resources and the environment, maintenance of national defense and security, as well as social order and safety ${ }^{3}$.

Science and technology are considered the foundation and driving forces for sustainable development. Modern, clean, and environment friendly technologies should be prioritized for use in the manufacturing sector. The goal of the Strategy itself is

... to transform the growth model by balancing extensive and intensive development; gradually shifting to green growth, low carbon economy, utilizing economically and efficiently all resources; minimizing the negative impact of economic activity on the environment; rationally exploiting and efficiently using natural resources, especially non-renewable resources; preventing and controlling pollution and degradation; remediating the environment; protecting and nourishing forests; conserving biodiversity; limiting harmful effects of natural disasters; and actively adapting to climate change, especially the rise of sea level $^{4}$.

The Sustainable Development Strategy for Vietnam 2011-2020 also outlines the tasks for this phase, including:

\footnotetext{
${ }^{2}$ See Decision No. 153/2004/QD-TTg dated August 17, 2004 of the Prime Minister promulgating the Oriented Strategy for Sustainable Development in Vietnam (Vietnam's Agenda 21).

${ }^{3}$ See Article 1 (I, 1) Decision No. 432/QD-TTg dated April 12, 2012 of the Prime Minister approving the Sustainable Development Strategy of Vietnam for the period 2011-2020.

${ }^{4}$ See Article 1 (I, 2,4) Decision No. 432/QD-TTg dated April 12, 2012 of the Prime Minister approving the Sustainable Development Strategy of Vietnam for the period 2011-2020.
} 
Designing and implementing a green growth strategy that will ensure the development of a low-carbon economy; using and saving energy efficiently; improving clean energy and renewable energy to ensure national energy security; gradually marketing energy prices, gradually increasing the share of clean energy and renewable energy in total energy consumption in Vietnam; establishing system of environmental-economic accounting, and adding more environmental and social aspects to the framework of the System of National Accounts (SNA).

Additionally, sustainable development and programs for local sustainability are missions that need to be implemented, with the Prime Minister issuing the "set of monitoring and evaluation indicators for local sustainable development in the period 2013-2020" (Decision No. 2157/QD-TTg dated 11-11-2013).

In order to implement the policy on sustainable development and green economic development, the Prime Minister issued Decision No. 1393/QD-TTg dated 25th September 2012 on approval of the "National Green Growth Strategy for the period 2011-2020 and vision to 2050".

This is the first comprehensive strategy for green development in Vietnam, which is suitable for the country's conditions and helps it catch up with the global trend. The national green growth strategy states:

Green growth is an important part of sustainable development, ensuring rapid, effective and sustainable economic development, and contributing significantly to the implementation of the National Strategy on climate change ... Green growth is based on increased investment in conservation, development, and effective use of natural capital, reduction of greenhouse gas emissions, improvement of environmental quality, thereby stimulating economic growth ${ }^{5}$.

Thus, the policy of green economy development is an important plan and measure to implement the policy of sustainable development set out by the Party, aiming at sustainable development for the country on the basis of the harmony among economic development, social equality, and environmental protection ${ }^{6}$.

On August 26, 2016, the Government issued Resolution No. 73/NQ-CP approving the investment policy for 21 Target Program for 2016-2020, including the Program to Respond to Climate Change and Green Growth. The goals of the program include: implementing solutions to adapt to the impacts of climate change and mitigate greenhouse gas emissions, ensuring human life and property safety; strengthening the capacity of people and natural systems to adapt to climate change; promoting green growth, low carbon economy, and enriching natural capital, which are the major trends in sustainable economic development; restructuring and enhancing economic institutions through promoting green industries, as well as encouraging sectors that both bring great benefit and use natural resources efficiently and economically; implementing the National Strategy on Climate Change, the National Green Growth Strategy, actively fulfilling Vietnam's commitment to protecting the earth's climate; planting and restoring 10,000 ha of coastal mangrove forest and watershed protection forests in order to adapt to climate change by 2020, absorb 2 million tons of $\mathrm{CO}_{2}$ per year, and create a stable livelihood for the people; reducing greenhouse gas emissions by between $8 \%$ and $10 \%$, from 2010 to 2020 ; reducing energy consumption by $1 \%$ to $1.5 \%$ per year; building a center for research, training, application, and transferring of green building technologies with the area of 50 ha in Vietnam; developing action plans for green growth at sectoral, regional, and local levels ${ }^{7}$.

\footnotetext{
${ }^{5}$ See Decision No. 1393/QD-TTg dated September 25, 2012 of the Prime Minister approving the "National Strategy on Green Growth for the period 2011-2020 with vision to 2050".

${ }^{6}$ See Decision No. 153/2004/QD-TTg dated August 17, 2004 of the Prime Minister promulgating the Oriented Strategy for Sustainable Development in Vietnam (Vietnam's Agenda 21).

7 See XIV. Target Program for climate change response and green growth (Appendix promulgated with Resolution No. 73/NQ-CP dated August 26, 2016 of the Government).
} 
On October 28, 2016, the Prime Minister issued Decision No. 2053/QD-TTg on the implementation of the Paris Climate Change Agreement. The plan identifies 5 groups of tasks: mitigating greenhouse gas emissions; adapting to climate change; preparing resource; establishing a transparent and open MRV (Monitoring, Reporting and Verification) system; and building and enhancing policies and institutions. Two groups of tasks, which are reducing greenhouse gas emission and adapting to climate change, have 38 out of 68 tasks, focusing on using clean energy, promoting green growth, restructuring industries, preventing and mitigating natural disasters, and ensuring stability of people's life ${ }^{8}$.

It can be affirmed that Vietnam has clearly recognized the role of sustainable development, green development, and expressed determination to catch up with the world. The Government of Vietnam has also created many programs and plans to implement the policy of green economy development.

Vietnam's policy on green economy development is clearly defined in official documents and being implemented at all levels. With the National Strategy and Action Plan on Sustainable Development and Green Growth, Green Economy, Climate Change Response, Vietnam has shown commitment and taken actions towards green development and sustainable development. The domestic and global practices for green economy development showed that Vietnam has great potential to follow with this trend in the near future and in the long run.

In order to implement green economy development policies in Vietnam in the context of global climate change, the following solutions need to be focused on:

Firstly, in terms of awareness, pay attention to communication and education in order to shift the previous "brown economy" mindset (which trades off economic development for environment quality) to the "green economy" mindset. This will create a high consensus among members of the society, from leaders to citizens and businesses and in turn, change the perceptions of a "green economy". In the professional education system, update the materials and lesson plans towards a "green economy" approach.

Secondly, ensure that policies and mechanisms facilitate the transition of the economic growth model, which focuses on economic restructuring and prioritizes the development of high technology with low carbon emissions, environment-friendly, energy-saving, pollution-free technology that restores resources and the ecosystem, accelerate the process of restructuring and privatization of public businesses in areas such as resource, energy, and heavy industry. This growth model calls for the development and implementation of standards which ensure biosecurity in aquaculture or improve energy efficiency, mobilize and promote the role of small and medium businesses and the role of the community in the implementation of green economy development policy. The proactive participation of the community will create a solid foundation for the realization of green economy, therefore, it is vital to raise the awareness of the community on green economy, to facilitate and mobilize community engagement in the development of green economy to step by step change the behavior of the society.

Thirdly, continuously invest in the development of science technology, encourage research and cooperation in the study of areas which help develop green economy such as renewable energy, resource-saving and energy-saving production technology, shift investment so as to reach about $2 \%$ of total annual budget expenditure for ecosystem restoration and environmental protection, etc.

\footnotetext{
${ }^{8}$ See Appendix: The tasks of implementing the Paris Agreement on climate change (Promulgated with Decision No. 2053 dated October 28, 2016 of the Prime Minister on the Plan for implementation of the Paris Agreement on climate change).
} 
Fourthly, reform the land use planning for urban development, transport development, industrial parks, export processing zones, and social welfare facilities so that land is reserved for trees, lakes, and technical infrastructure for the environment according to international standards.

Fifthly, reform the natural resources tax system and review environmental tax towards green economy development by making adjustments through the use of economic tools and financial/tax mechanisms in order to promote the efficient use of resources, especially valuable resources, to protect the environment, to maintain and develop natural ecosystems.

Sixthly, reform the macroeconomic indicators, to review and finalize the green GDP target, to improve the SNA so as to reflect all indicators of environmental accounting in the national accounts balance, etc.

Seventhly, review policies and mechanisms related to ecosystem services and invest in development and to link forest development with poverty reduction. In terms of the advantages of economic tools related to payments for forest environmental services, to supplement and complete these tools for nation-wide implementation and subsequent implementation in wetland ecosystems, marine ecosystems, coral reefs, etc.

Eighthly, strengthen international cooperation for green economy development in Vietnam, mobilize international resources, especially investment capital of $2 \%$ of the global GDP for green economy development and other financial mechanisms for forest development, etc. Better cooperation with other countries, international organizations, and international financial institutions is required so that Vietnam can overcome market failures related to the environment and strictly enforce international law and standards. For the Mekong River Delta region which is highly vulnerable to climate change, it is necessary to plan and invest appropriately and efficiently.

\section{Conclusions}

Therefore, in the digital age as well as in the context of global climate change, in order not to be left behind and to be in line with the common development trend of mankind, it is pivotal that Vietnam implements green economy development policies to achieve sustainable development and realize the following goals: fast and sustainable growth while ensuring progress and social equality; constant improvements to the quality of life while placing importance on environmental protection.

\section{References}

Decision No. 1393/QD-TTg dated September 25, 2012 of the Prime Minister approving the "National Strategy on Green Growth for the period 2011-2020 with vision to 2050".

Decision No. 153/2004/QD-TTg dated August 17, 2004 of the Prime Minister promulgating the Oriented Strategy for Sustainable Development in Vietnam (Vietnam's Agenda 21).

Decision No. 2053/QD-TTg on the Plan for implementation of the Paris Agreement on climate change.

Decision No. 432/QD-TTg dated April 12, 2012 of the Prime Minister approving the Sustainable Development Strategy of Vietnam for the period 2011-2020.

Kim, N., \& Nguyen, T. K. T. (2015). Global trends of green economy development. Vietnam Social Sciences, 5(90), 9-18.

Ngo, T. L., \& Vu, T. H. (2015). Sustainable development in Vietnam in the new context of globalization, international integration and climate change. Hanoi: National Political Publishing House.

Nguyen, T. D. (2016). Green growth and supporting finance policies. Journal of Natural Resources and Environment, dated June 24, 2016.

Target Program for climate change response and green growth (Appendix promulgated with Resolution No. 73/NQ-CP dated August 26, 2016 of the Government).

The Communist Party of Vietnam. (2016). The complete collection of party documents. Hanoi: National Political Publishing House. 
Tran, A. T., Bui, Q. T., Dao, H. M., \& Nguyen, T. T. (2015). Towards green economy in Vietnam: Greening production. Hanoi: Social Sciences Publishing House.

Tran, H. H. (2016). Global climate change and challenges for Vietnam. National Defense Journal, August 2016 issue.

Tran, N. N., Ha, H. N., Nguyen, S. T., Pham, T. T., \& Ha, H. T. (2016). Policies to promote green growth: International experiences and the current situation in Vietnam. Hanoi: National Political Publishing House.

UNEP. (2011). Towards a green economy-Pathways to sustainable development and poverty eradication. Retrieved from https://sustainabledevelopment.un.org/content/documents/126GER_synthesis_en.pdf

Vietnam Association for Conservation of Nature and Environment. (2018). Green economy for sustainable development in the context of climate change. Hanoi: National Political Publishing House. 